\title{
Performance and carcass traits of different commercial pig lines
}

\section{Desempenho e características de carcaça de suínos de diferentes linhagens}

\author{
Paulo Levi de Oliveira Carvalho ${ }^{1 *}$; Edmar Soares de Vasconcelos ${ }^{2}$; \\ Rodrigo Daniel Ansolin ; Kelly Aparecida Lorscheiter ${ }^{3}$; \\ Poliana Caroline da Silva Chambo ${ }^{3}$; Silvana Teixeira Carvalho'; \\ Ana Lúcia Almeida Santana ${ }^{4}$; Aparecida da Costa Oliveira ${ }^{5}$; Jansller Luiz Genova ${ }^{6}$
}

\begin{abstract}
The study objective was to evaluate the performance and the quantitative and qualitative carcass traits of three different commercial pig lines. Seventy-two animals were included, 24 animals of each lineage, 36 females and 36 immunocastrated males, with an initial and final average weight of $26 \pm 6.5 \mathrm{~kg}$ and $139.49 \pm 4.05 \mathrm{~kg}$, respectively. These animals were identified and distributed in randomised blocks in a $2 \times 3$ factorial analysis (two sexes and three lineages) with three replicates per treatment and four animals per experimental unit. The daily gain $(\mathrm{kg})$, feed conversion $\left(\mathrm{kg} \mathrm{kg}^{-1}\right)$, daily feed intake $(\mathrm{kg})$, carcass weight $(\mathrm{kg})$, backfat thickness $(\mathrm{mm})$, loin depth $(\mathrm{mm})$, lean meat percentage $(\%)$ lean beef kilograms ( $\mathrm{kg}$ ), marbling, water loss by leaking (\%), water loss by defrosting (\%), water loss by cooking $(\%)$, shear force $\left(\mathrm{kgf} \mathrm{cm}^{2-1}\right)$ and objective colour were measured. The results were submitted to analysis of variance and means (Tukey's test) of 5\%. There was no interaction between factors, and evaluating the factors separately did not yield significant differences between the lineages for any of the evaluated parameters. For the gender factor, a difference was obtained only for loin depth during the growth phase, lean meat percentage and defrosting water loss. Overall, the evaluated commercial lines were similar and gender influenced some performance parameters.
\end{abstract}

Key words: Daily gain. Feed conversion. Genetics. Meat quality. Shear force.

\section{Resumo}

Objetivou-se com o trabalho avaliar o desempenho e as características quantitativas e qualitativas da carcaça de suínos de três diferentes linhagens. No experimento foram utilizados 72 animais, sendo 24 animais de cada linhagem, 36 fêmeas e 36 machos imunocastrados, com peso médio inicial e final de $26 \pm 6,5$ e 139,49 $\pm 4,05 \mathrm{~kg}$. Os animais foram distribuídos em delineamento inteiramente casualizado

${ }^{1}$ Profs. Drs., Departamento de Zootecnia, Universidade Estadual do Oeste do Paraná, UNIOESTE, Marechal Cândido Rondon, PR, Brasil.E-mail: paulolevi@yahoo.com.br; silteixeira@gmail.com

2 Prof. Dr., Departamento de Agronomia, UNIOESTE, Marechal Cândido Rondon, PR, Brasil. E-mail: edmar.vasconcelos@, unioeste.br

${ }^{3}$ Discentes, Curso de Graduação em Zootecnia, UNIOESTE, Marechal Cândido Rondon, PR, Brasil. E-mail: rda_ansolin@ hotmail.com; kelly_aparecida_lorscheiter@hotmail.com; poliana_chambo@hotmail.com

${ }^{4}$ Discente do Curso de Doutorado no Programa de Pós-Graduação em Zootecnia, Universidade Federal da Bahia, UFB, Salvador, BA, Brasil. E-mail: ninhaemarc@hotmail.com

5 Pós-Doutoranda em Zootecnia, UNIOESTE, Marechal Cândido Rondon, PR, Brasil. E-mail: aparecidacostaoliveira@gmail.com

${ }^{6}$ Discente do Curso de Mestrado no Programa de Pós-Graduação em Zootecnia, UNIOESTE, Marechal Cândido Rondon, PR, Brasil. E-mail: jansllerg@gmail.com

* Author for correspondence 
em arranjo fatorial $2 \times 3$ ( 2 sexos e 3 linhagens), com três repetições por tratamento e quatro animais por unidade experimental, alojados em baias de alvenaria, onde permaneceram até o abate. Avaliouse o ganho diário de peso $(\mathrm{kg})$, conversão alimentar $\left(\mathrm{kg} \mathrm{kg}^{-1}\right)$, consumo diário de ração $(\mathrm{kg})$, peso de carcaça $(\mathrm{kg})$, espessura de toucinho $(\mathrm{ET}, \mathrm{mm})$, profundidade de lombo $(\mathrm{mm})$, percentual de carne magra $(\%)$, quilos de carne magra ( $\mathrm{kg}$ ), marmoreio, perda de água por gotejamento (\%), perda de água por descongelamento (\%), perda de água por cocção (\%), força de cisalhamento $\left(\mathrm{kgf} / \mathrm{cm}^{2}\right)$ e cor objetiva. Os resultados foram submetidos à análise de variância e teste de médias (tukey) a 5\%. Não houve interação entre os fatores e, avaliando os fatores separadamente, não obteve-se diferenças entre as linhagens para nenhum dos parâmetros avaliados e para o fator sexo obteve-se diferença apenas para profundidade de lombo na fase de crescimento, percentual de carne magra e perda de água por descongelamento. As linhagens avaliadas são semelhantes e o sexo influenciou em alguns parâmetros de desempenho.

Palavras-chave: Conversão alimentar. Força de cisalhamento. Ganho de peso. Genética. Qualidade da carne.

\section{Introduction}

The pig industry is of great economic importance to Brazil, as it generates a significant volume of exported meat, which makes Brazil the fourth largest pork producer and exporter in the world (ABPA, 2015). The pig industry also produces high quality animal protein and creates income. It is a sector that has undergone technological changes, particularly in order to increase productivity and reduce production costs, especially regarding food (SEBRAE, 2008). Positive results have already been seen based on the significant increase in production rates, which is mainly due to breeding programs, nutrition and management (BERTOL; SANTOS, 2013), as well as the welfare issues currently in force.

Industrial pig breeding began in the 1960's (NASCIMENTO, 2010), when the breeding programs mainly focused on animal growth rate, since both the meat and the fat had commercial value (ALVAREZ; GRACIOLI, 2012). However, that is currently not the case, since lean meat is the most desired by the market. Therefore, current breeding programs have invested in lean meat production, seeking superior lines for production of great performance flocks and carcass traits desirable for the market. According to Fávero and Figueiredo (2009), the flocks of male lines basically work with genotypes of Duroc, Large White, Pietrain, Hampshire and Belgian Landrace breeds, and synthetic strains are selected for high production of meat in the carcass and good feed conversion. The selection criteria normally used in the male line is the daily gain in lean meat, and the characteristics evaluated in the selection candidates are backfat thickness, feed intake and average daily gain.

One way to assess the genetic lineages is by quality of the traits, since it is expected that the phenotype has as good a performance as its genotype. However, it is noteworthy that in addition to genetic factors, the phenotype of an individual is influenced by several factors, such as food handling, nutrition quality, health status, production system, animal transport, pre-slaughter management, slaughter and post slaughtering meat processing and storage (NASCIMENTO, 2010). According to Lopes (2001), daily weight gain is the most important feature to evaluate the improvement of pigs, as it is an easy parameter to measure and possesses average heritability. The genetic correlation between weight gain and feed conversion is negative and high, and therefore only weight gain is included in the selection process.

In addition, the evaluation of quantitative and qualitative meat traits provides important information for the evaluation and selection of commercial strains. Given the above, this study aimed to evaluate the performance parameters and quantitative and qualitative carcass traits of genetically different pig strains in the growing and 
finishing phases.

\section{Materials and Methods}

The experiment was conducted in the Swine Sector of the Experimental Center from Universidade Estadual do Oeste do Paraná - Unioeste Campus Marechal Cândido Rondon - PR, located in Linha Guará in the period from May 10 to August 31, 2014.

Seventy-two pigs were used, 36 females and 36 immunocastrated males, with an average weight of $26 \pm 6.50 \mathrm{~kg}$. The pigs were composed of three genetic strains: (A) male AGPIC TG 415 superior genetics (B) male AGPIC TG 415 elite and genetics (C) male BP 375, mated with females F1 Landrace $\mathrm{x}$ Large White (LD x LW).

The animals were distributed in a completely randomised design in a $2 \times 3$ factorial arrangement (two sexes and three genetic lineages) with three replications. Each experimental unit consisted of four animals, which were housed in brick stalls of $5.8 \mathrm{~m}^{2}$ and provided with semi-automatic feeders and pacifier-type drinkers.

The diets were formulated according to the pigs' nutritional requirements for high genetic potential with superior performance, following the recommendations proposed by Rostagno et al. (2011), for growing and finishing phases.

The animals received plenty of food and water throughout the experimental period, and feed leftovers were collected, weighed and deducted from the initial provision to calculate the daily consumption. The individual weight of the animals was recorded at the beginning and end of each experimental phase. Based on these data, daily feed intake (DFI, $\mathrm{kg}$ day $^{-1}$ ), daily gain (DG, $\mathrm{kg} \mathrm{day}^{-1}$ ) and feed conversion (FC, $\mathrm{kg} \mathrm{kg}^{-1}$ ) were determined.

At the end of each experimental phase, backfat thickness was measured via loin depth at the $\mathrm{P} 2$ position (the region of the $10^{\text {th }}-11^{\text {th }}$ lumbar vertebrae) using an ultrasound device (SonoGrader, Renco®). Blood samples were collected from the cranial vena cava into test tubes, which were centrifuged $(3,000 \mathrm{rpm}$ for 15 minutes $)$ to obtain the serum in the Unioeste's Blood Analysis Laboratory. After centrifugation, $3 \mathrm{ml}$ of serum (in duplicate) were transferred to Eppendorf tubes and stored in a freezer $\left(-18{ }^{\circ} \mathrm{C}\right)$. These samples were used for urea analysis, which was performed with chemistry analysers (Flexor EL200 and ELI Tech kit, Clinical Systems).

When the pigs reached an average weight of $139.49 \pm 4.05 \mathrm{~kg}$, they were subjected to fasting for 12 hours for loading, which was held at night. The next day they were slaughtered at Frimesa, located in Medianeira - PR, following the humane slaughter rules (BRASIL, 2000).

Within 45 minutes, the carcasses were weighed to obtain the carcass weight $(\mathrm{CW}, \mathrm{kg})$, and then stored in a refrigerated chamber $\left( \pm 2^{\circ} \mathrm{C}\right)$ where they remained for 24 hours to allow rigor mortis to set in (BRIDI; SILVA, 2009). Subsequently, the backfat thickness (BT, mm), loin depth (LD, $\mathrm{mm}$ ), lean meat percentage (LM, \%) and lean meat kilograms (LM, kg) were measured according to routine slaughterhouse procedure, with the aid of an automatic pistol classification of HENNSSY brand.

To evaluate the qualitative carcass traits, the Longissimus dorsi muscle was removed from the left half of the carcass after rigor mortis, and was divided into samples of approximately $2.5 \mathrm{~cm}$ thick. Then, the water loss by leaking (WLL, \%), water loss by defrosting (WLD, \%), water loss by cooking (WLC, \%), shear force (SF, $\mathrm{kgf} \mathrm{cm}^{2-1}$ ), marbling (MARM) and objective colour (BRIDI; SILVA, 2009) were evaluated.

Data were submitted to analysis of variance and means comparison by the Tukey test at up to $5 \%$ probability. Statistical analyses were performed using the statistical software "Genes" (CRUZ, 2006). 


\section{Results and Discussion}

There was no interaction between the factors evaluated (strain $\mathrm{x}$ sex) $(\mathrm{P}>0.05)$; in other words, the strain and sex acted independently in all performance parameters (Table 1). While differences in performance have been documented between swine strains due to different breeding programs used in the selection process, the same was not observed in this study. The results of this study are similar to those of Guimarães et al. (2011), who evaluated pigs of different strains and sexes and also did not observe any interaction between factors and the performance characteristics.

Table 1. Influence of the bloodlines and sex in pigs performance parameters.

\begin{tabular}{lccccc}
\hline Strains & Initial Weight $(\mathrm{kg})$ & Final Weight $(\mathrm{kg})$ & DFI $(\mathrm{kg})$ & DG $(\mathrm{kg})$ & FC \\
\hline $\mathrm{A}$ & 24.75 & 141.00 & 2.49 & 1.03 & 2.43 \\
$\mathrm{~B}$ & 26.48 & 135.44 & 2.48 & 0.96 & 2.58 \\
$\mathrm{C}$ & 26.77 & 142.02 & 2.47 & 1.02 & 2.42 \\
\hline Average $G$ & 26.00 & 139.49 & 2.48 & 1.00 & 2.48 \\
\hline P value & - & 0.2478 & 0.9621 & 0.1901 & 0.1311 \\
\hline Sex & & & & & \\
Male & 25.85 & 142.90 & 2.53 & 1.04 & 2.45 \\
Female & 26.15 & 136.07 & 2.43 & 0.97 & 2.50 \\
\hline Pvalue & - & 0.0584 & 0.2025 & 0.0505 & 0.4229 \\
\hline Strain $x$ Sex & - & 0.6223 & 0.9855 & 0.7109 & 0.6795 \\
\hline
\end{tabular}

$\mathrm{DFI}=$ daily feed intake; $\mathrm{DG}=$ daly gain; $\mathrm{FC}=$ feed conversion; $\mathrm{A}=\mathrm{AGPIC} 415$ Superior $\mathrm{X} \mathrm{F}_{1}$ (Landrace $\mathrm{X}$ Large White); $\mathrm{B}=\mathrm{AGPIC}$ 415 ELITE X $F_{1}$ (Landrace X Large White); C - Biribas BP $375 \mathrm{X} \mathrm{F}_{1}$ (Landrace X Large White); Tukey Test $(\mathrm{P}=0,05)$.

The animals' initial and final weights were similar, and hence the weight gain average was also similar between treatments for the lineage factor. For the sex factor, the males' final weights were $4.8 \%$ higher than the female average, however, the mean test detected no difference $(\mathrm{P}>0.05)$. The daily feed intake was within the expected average, based on a study by Rostagno et al. (2011) who established swine average values for DFI of $2.15 \mathrm{~kg}$ for barrows in the growth phase and $3.03 \mathrm{~kg}$ in the finishing phase.

Previous studies demonstrated that male pigs castrated either via immunisation or surgery have higher daily feed intake, higher daily weight gain and worse feed conversion when compared to females, which was attributed to lower levels of serum androgens (MORAES et al., 2010; SILVA et al., 2012). However, this higher feed intake is not only related to a higher body weight but also to increased lipid deposition, where demand for nutrients is greater, which justifies the inferior feed conversion observed for males versus females (BERTOL et al., 2013; CALDARA et al., 2013).

The average values for feed conversion were within the reference values of 2.4 and 2.5 (ROSTAGNO et al., 2011). The feed conversion did not differ between strains studied; one can therefore infer that the production cost for the growing-finishing phase was similar among the three genetic groups. Contrary results were highlighted in a study by Bertol et al. (2013), who observed a deterioration in feed conversion when comparing three genotypes $(\mathrm{DC} \times \mathrm{F} 1$, MS-115 $\times$ F1 and MS-115 $\times$ MO). In that study, the feed conversion of the MS-115 x MO genotype was lower than the others, which may be explained by 
the less efficient use of dietary nutrients by animal weight gain.

When evaluating backfat thickness and loin depth during the growth and termination phases via real-time ultrasonography, it was found that backfat thickness was not influenced by any of the evaluated factors $(\mathrm{P}>0.05)$, and loin depth differed for the sex factor but only in the growth phase $(\mathrm{P}=$ 0.0023 ) (Table 2).

Table 2. Backfat thickness and loin depth evaluated in pigs from commercial strains in the growth phase and termination.

\begin{tabular}{lcccc}
\hline \multirow{2}{*}{ Strains } & \multicolumn{2}{c}{ Backfat thickness $(\mathrm{mm})$} & \multicolumn{2}{c}{ Loin depth $(\mathrm{mm})$} \\
\cline { 2 - 5 } & Growth & Termination & Growth & Termination \\
\hline $\mathrm{A}$ & 8.08 & 12.79 & 45.58 & 67.17 \\
$\mathrm{~B}$ & 8.39 & 12.65 & 48.30 & 70.04 \\
$\mathrm{C}$ & 7.92 & 12.54 & 46.17 & 66.21 \\
\hline Average $G$ & 8.13 & 12.66 & 46.66 & 67.77 \\
\hline$P$ value & 0.5676 & 0.9494 & 0.0561 & 0.0907 \\
\hline Sex & & & & \\
Male & 7.80 & 12.54 & $45.11 \mathrm{~b}$ & 66.80 \\
Female & 8.44 & 12.78 & $48.17 \mathrm{a}$ & 68.72 \\
\hline$P$ value & 0.0863 & 0.7128 & 0.0023 & 0.2048 \\
\hline Strain $x$ Sex & 0.0649 & 0.6121 & 0.7397 & 0.9952 \\
\hline A A
\end{tabular}

$\mathrm{A}=\mathrm{AGPIC} 415$ Superior $\mathrm{X} \mathrm{F}_{1}$ (Landrace $\mathrm{X}$ Large White); $\mathrm{B}=\mathrm{AGPIC} 415$ ELITE X $\mathrm{F}_{1}$ (Landrace $\mathrm{X}$ Large White); $\mathrm{C}$ - Biribas BP $375 \mathrm{X} \mathrm{F}_{1}$ (Landrace $\mathrm{X}$ Large White). Averages followed by different letters in the same column differ by Tukey test $(\mathrm{P}=0.05)$.

However, backfat thickness values between strains and genders for both growth and termination stages were close and similar to the work conducted by Dutra Junior et al. (2001), who obtained a mean of $9.75 \mathrm{~mm}$ in the growth phase, but in the finishing phase obtained a value $16.40 \mathrm{~mm}$ higher than in the present study. In practice, backfat thickness is an important variable to determine the quality of the swine carcass, and its evaluation by in vivo ultrasound is a useful tool for decision making, since one of the main goals set by the meatpacking industry is the reduction in this variable.

Kiefer et al. (2014) evaluated genetically improved pigs and observed through ultrasonography that backfat showed a highly negative correlation with lean meat percentage $(\mathrm{r}=$ - 0.91). These authors stated that backfat thickness is associated with the amount of fat in the carcass, and is inversely proportional to the amount of meat. These responses show a direct correlation between backfat thickness and percentage of lean meat, both in the measures taken by ultrasound in vivo and those made directly in the carcass.

For the variable loin depth (Table 2), only sex influenced the growth phase, where females had greater depth with regard to males with $48.17 \mathrm{~mm}$, as in the finishing phase the values were similar between the sexes. According to Moraes et al. (2010), sex can influence carcass development because, when assessing males and females in the growth phase, subject to the same nutrition and weighing similarly at slaughter, females tend to have higher protein deposition and smaller lipid deposition compared to males. Accordingly, Silva et al. (2015) observed that females reached larger depth values in the sirloin and ribeye areas and had more lean meat in relation to barrows, which corroborates the results presented in this paper. 
The results of serum urea in pigs are shown in Table 3. The evaluated factors (gender x strain) were independent of behaviour, in other words, there was no interaction between them and the variable in question $(\mathrm{P}>0.05)$.

When evaluating the factors separately, a significant difference was obtained in the concentration of serum urea between strains in the growth phase $(\mathrm{P}<0.011)$ by the $\mathrm{F}$ test analysis of variance, although with the means test a difference was not detected, and in the finishing phase there was no difference $(\mathrm{P}>0.05)$. Given this result for serum urea, it is possible to speculate that the growing strains influence the use of dietary protein, and strain " $\mathrm{A}$ " presented the best results, followed by strain " $\mathrm{B}$ " and then " $\mathrm{C}$ ". Growing and finishing pigs have different capabilities in the use of protein and lean tissue deposition, thus the nitrogen in urea can be a parameter to indicate the use and quality of protein in pig diets. The lower urea level in blood serum of the "A" strain indicates greater utilisation of dietary nitrogen and reduced urea synthesis. In pigs under normal conditions without pathology, the concentration of urea in the blood may represent the animal's nutritional status as well as the quality of protein intake (WEI; ZIMMERMAN, 2003), since urea nitrogen is an effective parameter to indicate the utilisation of dietary amino acids by pigs (FRAGA et al., 2008).

Table 3. Urea concentrations $(\mathrm{mg} / \mathrm{mL})$ of three pigs' strains in the growth and termination phase.

\begin{tabular}{lcc}
\hline Strains & Growth & Termination \\
\hline $\mathrm{A}$ & 187.97 & 369.72 \\
$\mathrm{~B}$ & 190.44 & 345.38 \\
$\mathrm{C}$ & 201.35 & 363.42 \\
\hline Average G & 193.82 & 356.23 \\
\hline Pvalue & $0.0115^{*}$ & 0.0647 \\
\hline Sex & & \\
Male & 171.77 & 385.53 \\
Female & 214.74 & 333.48 \\
\hline Pvalue & 0.9999 & 0.9999 \\
\hline Strain $x$ Sex & 0.2563 & 0.9999 \\
\hline A A A 415 & $-\mathrm{A}$ & \\
\hline
\end{tabular}

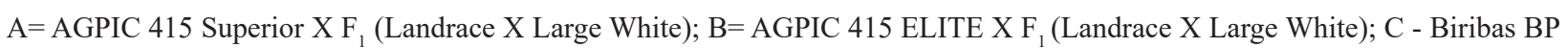
$375 \mathrm{X} \mathrm{F}_{1}$ (Landrace $\mathrm{X}$ Large White). * Significant difference $(\mathrm{P}=0,05)$ only in $\mathrm{F}$ test.

Quantitative traits evaluated in the carcasses are shown in Table 4. There was no interaction among the factors for any parameter analysed ( $\mathrm{P}$ $>0.05)$. When evaluating the factors separately, a difference was obtained for the percentage of lean meat $(\mathrm{CM})$ based on sex $(\mathrm{P}=0.038)$, whereas lineage did not affect the behaviour of any variable $(\mathrm{P}>0.05)$.

The mean values of the studied parameters were close between the lineages, whereas gender values were discrepant, which contributed to the difference $(\mathrm{P}<0.05)$ in percentage of lean meat, in which females had higher average values compared to males. In other words, the fat deposition in the carcass of females was numerically smaller, which can be seen by backfat thickness (Table 4). There is a negative correlation between the percentage of lean meat and backfat thickness (KIEFER et al., 2014). In other words, the greater the backfat thickness, the lower the amount of lean meat, justifying the results observed in this work. 
Table 4. Meat quantitative traits of different strains in the growth and termination phase.

\begin{tabular}{lccccc}
\hline Strain & CW $(\mathrm{kg})$ & BT $(\mathrm{mm})$ & LD $(\mathrm{mm})$ & LM $(\%)$ & LM $(\mathrm{kg})$ \\
\hline A & 103.04 & 17.98 & 58.10 & 59.69 & 61.06 \\
B & 102.91 & 18.50 & 59.50 & 59.70 & 61.50 \\
C & 102.14 & 17.49 & 58.39 & 60.16 & 61.40 \\
\hline Average G & 102.70 & 17.98 & 58.68 & 59.86 & 61.33 \\
\hline Pvalue & 0.9503 & 0.7626 & 0.7368 & 0.88282 & 0.9673 \\
\hline Sex & & & & \\
Male & 105.08 & 19.02 & 57.91 & $58.87 \mathrm{~b}$ & 61.72 \\
Female & 100.45 & 16.75 & 59.52 & $60.84 \mathrm{a}$ & 60.89 \\
\hline Pvalue & 0.6539 & 0.0596 & 0.3130 & 0.0382 & 0.5511 \\
\hline Strain $x$ Sex & 0.6248 & 0.4707 & 0.5685 & 0.69550 & 0.4445 \\
\hline
\end{tabular}

$\mathrm{CW}=$ Carcass weight; $\mathrm{BT}=$ backfat thikness; $\mathrm{LD}=$ loin depth; $\mathrm{LM}(\%)=$ lean meat percentage; $\mathrm{LM}(\mathrm{kg})=$ lean meat kilograms. $\mathrm{A}=$

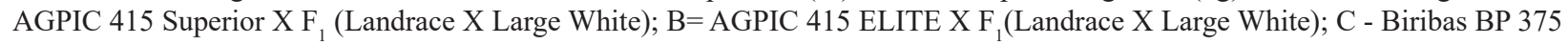
$\mathrm{X} \mathrm{F}_{1}$ (Landrace $\mathrm{X}$ Large White). Average followed by different letter in the column differ statistically by Tukey test $(\mathrm{P}<0.05)$.

An interaction was observed $(\mathrm{P}=0.0373)$ among the factors evaluated for variable water loss after thawing by analysis of variance (Table 5); however, when the mean test was applied (Tukey) a difference was not detected between factors (strain and sex). While there was no difference (P $>0.05)$, the male carcasses had lower water loss on thawing compared to the female carcasses. This result may be related to the higher marbling value of meat, given that the male carcasses showed a higher marbling value. In other words, there was more intramuscular fat in the meat relative to the females, which may have facilitated water retention since fat protects the substrate from adverse effects of low cooling temperatures and excessive water loss by the formation of ice crystals within the cells. These crystals cause cell damage when the meat is defrosted, with increased water loss as well as loss of other nutrients such as proteins, minerals and vitamins (SAÑUDO et al., 2000).

Table 5. Pigs' carcass qualitative traits of different strains in the growing and finishing phase.

\begin{tabular}{lccccc}
\hline Strains & WLL $(\%)$ & WLD $(\%)$ & WLC $(\%)$ & SF $\left(\mathrm{kgf}^{2-1}\right)$ & MARM \\
\hline $\mathrm{A}$ & 2.91 & 7.29 & 21.73 & 7.77 & 2.17 \\
$\mathrm{~B}$ & 1.87 & 7.78 & 21.56 & 9.40 & 2.50 \\
$\mathrm{C}$ & 2.13 & 7.01 & 21.32 & 7.40 & 2.04 \\
\hline Average $G$ & 2.53 & 7.35 & 21.53 & 8.22 & 2.19 \\
\hline P value & 0.8869 & 0.4375 & 0.9306 & 0.4975 & 0.3977 \\
\hline Sex & & & & & \\
Male & 2.06 & 7.02 & 21.34 & 8.54 & 2.24 \\
Female & 3.00 & 7.68 & 21.55 & 7.91 & 2.15 \\
\hline Pvalue & 0.4610 & 0.1997 & 0.9873 & 0.7180 & 0.6315 \\
\hline Strain $\boldsymbol{x}$ Sex & 0.9002 & 0.0373 & 0.6260 & 0.8143 & 0.1231 \\
\hline
\end{tabular}

$\mathrm{WLL}=$ water loss by leaking; $\mathrm{WLD}=$ water loss by defrosting; ${ }^{3} \mathrm{WLC}=$ water loss by cooking; $\mathrm{SF}=$ shear force; $\mathrm{MARM}=$ marbling.

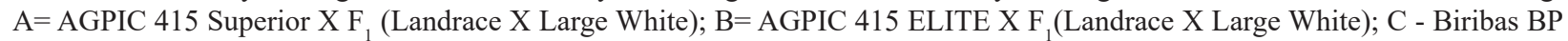
$375 \mathrm{X} \mathrm{F}_{1}$ (Landrace X Large White). Averages followed by different letter in the column differ statistically by tukey Test $(P<0,05)$. 
Ideally, the intramuscular fat percentage should be between 2 to $4 \%$ to ensure high sensory quality of pork, because of its effect on juiciness and tenderness and the flavor and texture of cured processed products (NPPC, 1998; ALONSO et al., 2010). Thus, according to the results obtained, it can be inferred that the values for all strains and for sex were within the ideal range. However, Bertol et al. (2013) observed lower values of 1.29, 1.87 and $2.64 \%$ for the genetic groups MS115xF1, MS115xMO and DCxF1, respectively.

The variables of water loss by leaking and water loss by cooking showed no difference between strains and sex. The highest meat constituent is water, which is approximately $75 \%$ of meat by weight. Water loss, either by leaking or cooking, is not ideal as it reduces the nutritional quality of the meat by reducing protein soluble vitamins and minerals, in addition to reducing the palatability
(KIM et al., 2013). Accordingly, the meat's ability to retain water in the presence of external factors influences the post-slaughter weight, which is of great economic value to the industry (RAMOS; GOMIDE, 2007).

For the shear force, the average value between the strains was $8.22 \mathrm{kgf} \mathrm{cm}^{2-1}(\mathrm{P}>0.05)$, with no difference in softness. This result was consistent with previous studies that evaluated different genetic groups of finishing pigs (GARBOSSA et al., 2013; MUHLISIN et al., 2014).

The pork colour was not influenced by the evaluated factors (strain $\mathrm{x}$ sex) (Table 6). While there were no changes to the colour, this variable is considered important for meat quality. In addition to attracting the consumer and creating a positive first impression, the colour is also used to set limits affecting the classification and shelf life of the meat (KIM et al., 2013).

Table 6. Effect of different strains and sex in the pork color in the growth and termination phase.

\begin{tabular}{lccccc}
\hline Strains & $\mathrm{L}^{*}$ & $\mathrm{a}^{*}$ & $\mathrm{~b}^{*}$ & Chroma & $\mathrm{H}$ \\
\hline $\mathrm{A}$ & 50.11 & 4.51 & 4.42 & 6.35 & 0.75 \\
$\mathrm{~B}$ & 49.58 & 4.97 & 4.52 & 6.79 & 0.75 \\
$\mathrm{C}$ & 50.57 & 4.38 & 4.45 & 6.27 & 0.79 \\
\hline Average G & 50.08 & 4.62 & 4.46 & 6.47 & 0.76 \\
\hline P valur & 0.6473 & 0.1911 & 0.9466 & 0.4650 & 0.3344 \\
\hline Sex & & & & \\
Male & 49.61 & 4.34 & 4.24 & 6.11 & 0.76 \\
Female & 50.58 & 4.89 & 4.69 & 6.83 & 0.76 \\
\hline P value & 0.4138 & 0.0669 & 0.3443 & 0.1188 & 0.5783 \\
\hline Strain $x$ Sex & 0.8346 & 0.4745 & 0.3474 & 0.4046 & 0.3314 \\
\hline
\end{tabular}

$\mathrm{L}^{*}=$ brightness (black - white); $\mathrm{a}^{*}=$ saturation (green - red); $\mathrm{b}^{*}=$ tone (blue - yellow); chroma= purity of color (gray); h= hue (red

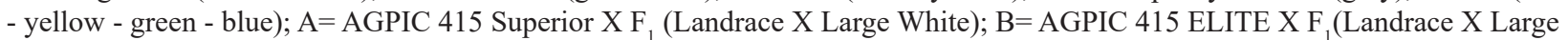
White); C - Biribas BP 375 X F $_{1}$ (Landrace X Large White). Averages followed by different letter in the column differ statistically by Tukey test $(P<0,05)$.

However, some studies assessing genetic influences on pork colour are divergent (LATORRE et al., 2003). When comparing different strains, Rosa et al. (2008) and Muhlisin et al. (2014) obtained differences for this variable based on both lineage and sex. Bertol et al. (2013) observed a significant difference in $\mathrm{L}^{*}$ and $\mathrm{a}^{*}$ only for genotypes. The effect of gender on meat colour is not as strong as its effect on marbling, however studies have shown higher reflectance values $a^{*}$ and $b^{*}$ in meat from 
male pigs than in female pigs (LATORRE et al., 2003; DUGAN et al., 2004).

\section{Conclusion}

The evaluated strains were similar in terms of performance traits and meat quality, and all of them performed well. Gender did have an influence, with better results for females in the variables loin depth, growth phase and lean meat percentage.

\section{Acknowledgements}

The authors acknowledgment Copagril Marechal Cândido Rondon Unit for partnership in the research.

\section{References}

ALONSO, V.; CAMPO, M. M.; PROVINCIAL, L.; RONCALÉS, P.; BELTRÁN, J. A. Effect of protein level in commercial diets on pork meat quality. Meat Science, Barking, v. 85, n. 1, p. 7-14, 2010.

ALVAREZ, R. H.; GRACIOLI, D. Algumas particularidades das linhagens modernas de suínos. Pesquisa \& Tecnologia, Campinas, v. 9, n. 1, p. 1-6, 2012.

ASSOCIAÇÃO BRASILEIRA DE PROTEÍNA ANIMAL - ABPA. Relatório anual. São Paulo: ABPA, 2015. Disponível em: <http://abpa-br.com.br/files/ RelatorioAnual_UBABEF_2015_DIGITAL.pdf $>$. Acesso em: 15 maio 2016.

BERTOL, T. M.; CAMPOS, R. M. L.; LUDKE, J. V.; TERRA, N. N.; FIGUEIREDO, E. A. P.; COLDEBELLA, A.; SANTOS FILHO, J. I.; KAWSKI, V. L.; LEHR, N. M. Effects of genotype and dietary oil supplementation on performance, carcass traits, pork quality and fatty acid composition of backfat and intramuscular fat. Meat Science, Barking, v. 93, n. 3, p. 507-516, 2013.

BERTOL, T. M.; SANTOS FILHO, J. I. O que é bom pode ficar ainda melhor. Suinocultura Industrial, Itu, v. 253, n. 4, p. 20-26, 2013.

BRASIL. Ministério da Agricultura, Pecuária e Abastecimento. Instrução Normativa n.03, de 7 de janeiro de 2000. Regulamento técnico de métodos de insensibilização para o abate humanitário de animais de açougue. Diário Oficial [da] União, Brasília, 24 jan. 2000. Seção 2, p. 14-16.
BRIDI, A. M.; SILVA, C. A. Avaliação da carne suína. 2. ed. Londrina: Editora Midiograf, 2009. 120p .

CALDARA, F. R.; MOI, M.; SANTOS, L. S.; PAZ, I. C. L. A.; GARCIA, R. G.; NÄÄS, I. A.; FERNANDES, A. R. M. Carcass characteristics and qualitative attributes of pork from immunocastrated animals. Australasian Journal Animal Science, Seoul, v. 26, n. 11, p. 16301377, 2013.

CRUZ, C. D. Programa Genes: estatística experimental e matrizes. Viçosa, MG: UFV, 2006. 285 p. v. 1.

DUGAN, M. E. R.; AALHUS, J. L.; ROBERTSON, W. M.; ROLLAND, D. C.; LARSEN, I. L. Practical dietary levels of canola oil and tallow have differing effects on gilt and barrow performance and carcass composition. Canadian Journal of Animal Science, Ottawa, v. 84, n. 4, p. 661-671, 2004.

DUTRA JUNIOR, W. M.; FERREIRA, A. S.; TAROUCO, J. U.; EUCLYDES, R. F.; DONZELE, J. L.; CARDOSO, L. L. estimativas de rendimentos de cortes comerciais e de tecidos de suínos em diferentes pesos de abate pela técnica de ultra-sonografia em tempo real. Revista Brasileira de Zootecnia, Viçosa, MG, v. 30, n. 4, p. 1243-1250, 2001.

FÁVERO, J. A.; FIGUEIREDO, E. A. P. Evolução do melhoramento genético de suíno no Brasil. Revista CERES, Viçosa, MG, v. 56, n. 4, p. 420-427, 2009.

FRAGA, A. L.; MOREIRA, I.; FURLAN, A. C.; BASTOS, A. O.; OLIVEIRA, R. P.; MURAKAMI, A. E. Lysine requeriment of starting barrows from two genetic groups fe don low crude protein diets. Brazilian Archives of Biology and Technology, Curitiba, v. 51, n. 1, p. 49-56, 2008.

GARBOSSA, C. A. P.; SOUSA, R. V.; CANTARELLI, V. S.; PIMENTA, M. E. S. G.; ZANGERONIMO, M. G.; SILVEIRA, H.; KURIBAYASHI, T. H.; CERQUEIRA, L. G. S. Ractopamine levels on performance, carcass characteristics and quality of pig meat. Revista Brasileira de Zootecnia, Viçosa, MG, v. 42, n. 5, p. 325-333, 2013.

GUIMARÃES, G. G.; MURATA, L. S.; MCMANUS, C.; SANTANA, A. P.; RECKZIEGEL, G. C.; AMÂNCIO, A. S.; JARDIM-FILHO, R. M.; SOBRINHO, A. J. F. Desempenho de suínos de dois cruzamentos de linhagens comerciais criados em cama sobreposta. Archivos de Zootecnia, Córdoba, v. 60, n. 229, p. 11-18, 2011.

KIEFER, C.; SUGUISAWA, L.; GONÇALVES, L. M. P.; SOUZA, K. M. R.; MARQUES, A. C. W.; SUGUISAWA, J. M.; SANTOS, A. P. Avaliação da carcaça de suínos imunocastrados pela técnica da ultrassonografia em tempo real. Revista Agrarian, Dourados, v. 7, n. 23, p. 118-123, 2014. 
KIM, G. D.; KIM, B. W.; JEONG, J. Y.; HUR, S. J.; CHO, I. C.; LIM, H. T.; JOO, S. T. Relationship of carcass weight to muscle fiber characteristics and pork quality of crossbred (Korean Native Black Pig $\times$ Landrace) F2 pigs. Food Bioprocess Technology, Dordrecht, v. 6, n. 2, p. 522-529, 2013.

LATORRE, M. A.; LÁZARO, R.; GRACIA, M. I.; NIETO, M.; MATEOS, G. G. Effect of sex and terminal sire genotype on performance, carcass characteristics, and meat quality of pigs slaughtered at $117 \mathrm{~kg}$ body weight. Meat Science, Barking, v. 65, n. 4, p. 1369-1377, 2003.

LOPES, P. S.; FREITAS, R. T. F.; FERREIRA, A. S. Melhoramento de suínos. Viçosa: UFV, 2001. 39 p. (Caderno Didático, 37).

MORAES, E.; KIEFER, C.; SILVA, I. S. Ractopamina em dietas para suínos machos imunocastrados, castrados e fêmeas. Ciência Rural, Santa Maria, v. 40, n. 2, p. 409414, 2010.

MUHLISIN, S. M. K.; PANJONO; LEE, S. J.; LEE, J. K.; LEE, S. K. Effects of crossbreeding and gender on the carcass traits and meat quality of korean native black pig and duroc crossbred. Asian-Australasian Journal of Animal Sciences, Seoul, v. 27, n. 7, p. 1019-1025, 2014.

NASCIMENTO, J. D. Fatores determinantes do rendimento de carne magra em suinos: melhoramento genético. [s.1.] : s.n], 2010. In: <http://www.cnpsa. embrapa.br/sgc/sgc_publicacoes/anais0104_donisete. pdf $>$. Acesso em: 07 jun. 2014.

NATIONAL PORK PRODUCERS COUNCIL - NPPC. Pork quality targets. Des Moines: IA, 1998.

RAMOS, E. M.; GOMIDE, L. A. M. Avaliação da qualidade de carnes: fundamentos e metodologias. Viçosa: UFV, 2007. 599 p.

ROSA, A. F.; GOMES, J. D. F.; MARTELLI, M. R.; SOBRAL, P. J. A.; LIMA, C. G. Qualidade da carne de suínos de três linhagens genéticas comerciais em diferentes pesos de abate. Ciência Rural, Santa Maria, v. 38, n. 5, p. 1394-1401, 2008.
ROSTAGNO, H. S.; ALBINO, L. F. T.; DONZELE, J. L; GOMES, P. C.; OLIVEIRA, R. F.; LOPES, D. C.; FERREIRA, A. S.; BARRETO, S. L. T. Tabelas brasileiras para aves e suinos: composição de alimentos e exigências nutricionais. 3. ed. Viçosa, MG: Universidade Federal de Viçosa, 2011. 252 p.

SAÑUDO, C.; AFONSO, M.; SÁNCHEZ, A.; TEIXEIRA, A. Carcass and meat quality in light lambs from different fat classes in EU carcass classification system. Meat Science, Barking, v. 56, n. 1, p. 89-94, 2000.

SERVIÇO BRASILEIRO DE APOIO ÀS MICRO E PEQUENAS EMPRESAS - SEBRAE. Suinocultura, carne in natura, embutidos e defumados - estudos de mercado. São Paulo: SEBRAE/espm, 2008. Disponível em: $\quad<$ http://bis.sebrae.com.br/GestorRepositorio/ ARQUIVOS_CHRONUS/bds/bds.nsf/ E700C099069C C7A8832574DC004BECAE/\$File/NT000390A6.pdf>. Acesso em: 07 jul. 2014.

SILVA, C. A.; BOROSKY, J. C.; BRIDI, A. M.; ROCHA, M. A.; SILVA, R. A. M.; PACHECO, G. D. Avaliação do desempenho, da produção de fezes e da digestibilidade de nutrientes em suínos de diferentes grupos genéticos. Semina: Ciências Agrárias, Londrina, v. 33, p. 33153322, 2012. Suplemento 2.

SILVA, R. A. M.; PACHECO, G. D.; VINOKUROVAS, S. L.; OLIVEIRA, E. R.; GAVIOLI, D. F.; LOZANO, A. P.; AGOSTINI, P. S.; BRIDI, A. M.; SILVA, C. A. Associação de ractopamina e vitaminas antioxidantes para suínos em terminação. Ciência Rural, Santa Maria, v. 45, n. 2, p. 311-316, 2015.

WEI, R.; ZIMMERMAN, D. R. An evaluation of the NRC (1998) growth model in estimating lysine requirements of barrows with a lean growth rate of 348 g/d. Journal of Animal Science, Champaign, v. 81, n. 7, p. 1772-1780, 2003. 